\title{
8
}

\section{THE RELEVANCE OF}

\section{MASCULINITIES FOR FORESTS AND THEIR MANAGEMENT}

\section{Introduction}

I began this book with my own personal experience of masculinity throughout the US and globally, in earlier times. The 'meat' of the book has been the four cases: Bushler Bay in the rural US (mid-1970s), Long Segar in rural Kalimantan (late 1970s and beyond), Sitiung in rural Sumatra (mid-1980s) and elite forestry researchers globally (1990s and 2000s), with three more recent updates in Chapter 7. From these cases, analyzed in depth, I have demonstrated some of the variety that exists globally in forest masculinities and some of the varying choices and preferences that men in these forests have made regarding their own identities. Here I turn to a summary of the forest implications of these variations in masculinities.

\section{Forest relevance}

Feminists were interested not just in explaining how sciences worked, leaving their projects and practices unchanged. . . Instead, feminists aimed to change scientific practice, to produce empirically and theoretically more successful research. . . . Moreover, as feminist critics of the First World's development policies in the Third World began to examine the destructive consequences of the imposition in the Third world of First World scientific and technological assumptions and practices, it became clear that far deeper and broader changes in scientific practice and philosophies of science would be required if sciences were to speak also for the 70 percent or so of the world's most economically and politically vulnerable women, men and children ...

(Harding 2004, p. 31; my emphasis)

This has indeed been part of my motivation in writing this book. I have highlighted the differences among communities-specifically in the ways they 
viewed and practised their masculinities - in and near different forests. And I have hoped, by bringing these differences to light, to influence the ways forestry science and 'development' are practised. But to do that, there remains another task: to show how these differences relate specifically to forest management policies and practices. That is my goal here.

Understanding men, as individuals central to global views of forests, is fundamental if we seek styles of forest management that benefit both environments and their inhabitants. Environments and cultures (integrally related to being human) vary enormously. Accordingly, men's relations with forests vary. Good management takes into account the knowledge, capabilities, needs and goals of the people who live in and near such forests. Taking these differences into account becomes even more important as we strive to work collaboratively with local people to maintain forests and forest cultures and to improve forest management generally. We need to become attuned to the impacts of power differences - particularly the power we ourselves often inadvertently wield - in our interactions with communities (see Rosendahl et al. 2015, who argue for what they call 'strong objectivity', for a nice analysis of one common and relevant and inadvertently marginalizing scenario).

Like these authors, we need to consider such issues from a transdisciplinary perspective. In this book, I have used my own methodological and analytical tools, informed both by my anthropological training and by decades of work with foresters, but I recognize that were I to collaborate with a forester, he or she might come up with additional ways that these social facts bear on forests and vice versa. A forester might be able to suggest specific and practical ways to alter management that would have allowed us to avoid or moderate the dislocations discussed in some of the cases below - an endeavour that remains for future analyses.

In the following sections, I consider the forest implications of the specific masculinities described in this book. The trajectories over time may be helpful to us in anticipating changes in the future and developing more effective and benign forest management strategies.

\section{Forest relevance of Bushler Bay masculinities}

\section{As the timber wars began (1970s)}

The implications of forest management were quite different for Local men visà-vis Public Employee men in Bushler Bay, though both were affected by the community's strong gender polarity. Men did not want to be like women and most went to considerable effort to ensure that they were not. For Local men, this meant emphasizing their involvement in an occupation that occurred outdoors and required physical strength, endurance and courage. Logging represented a key chord in achieving manliness and a crucial tone in most loggers' songs. For Public Employee men, symbolized within the community by US 
Forest Service employment, secure breadwinning was the central tone they plucked.

US government policies about forest management-sparked by concerns about the spotted owl and the marbled murrelet-had different implications for the men who plucked these divergent harp strings. Reductions in timber sales by the US Forest Service (USFS) in this area where most forests were indeed federally owned meant loss of income, but more importantly for Local men, loss of opportunities to fulfill their most cherished masculine ideals (physical strength, outdoor work, love of nature, independence). Such loss was a direct attack on their feelings about their manhood and sense of self.

For Public Employee men, there were similar though less extreme, dislocations. The reduction in timber sales meant a reduction in staffing of the local USFS office and resulting uncertainty about continued employment as well (the breadwinning harp string so central to Public Employee men).

Compounding these disharmonies was the wider American emphasis on competition-part of the harp itself. Competition among both Locals and Public Employees increased as forest-related economic opportunities diminished for each, with a corresponding diminution of community cooperation. Anger and distrust among Locals, much of which was directed toward the Public Employees who had to enforce the national laws, grew, exacerbated by feelings of powerlessness as their voices carried no weight in the federal decision-making process that so harshly affected them. ${ }^{1}$ Locals felt they were fighting for their way of life, and they were losing. Public Employees, though also unhappy, were more likely to have employment options in other parts of the country, moving, but remaining employed, secure, with employment benefits-and thus their masculinity intact. Anger, dislocation and anomie pervaded the community.

The harp - the cultural and institutional framework-represented in Bushler Bay carried with it other losses as well. The knowledge that these men of the forest held, from long and intimate experience in it, was lost to the US Forest Service and its formal managers. There were no meaningful feedback channels for local information, knowledge, wisdom to go 'up' the bureaucratic ladder to those who made the decisions about forests.

Additionally, the traditional emphasis on timber, and the assumptions by formal forest managers that forests were masculine places, resulted in even less attention to women's forest knowledge, practices and hopes for the future. At that time, this may have been an advantage for rural women, as the USFS paid little attention to subsistence uses (berries, mushrooms, ferns and other NTFPs), and both men and women could manage and harvest, consistent with community norms. But it was a loss again for the USFS of local knowledge about these resources.

Finally, the lack of knowledge by USFS employees about Local lifeways and the likely impacts of federal forest management actions eventually represented a loss of cultural diversity as urbanites 'invaded'—and a loss to humanity. 


\section{Bushler Bay as a retirement community (2017)}

Busher Bay is no longer a logging community. The logging way of life has virtually disappeared, replaced by another kind of forest reliance, more closely linked to conservation. Whereas in the past, people's livelihoods depended on the forest, now the forest draws in-migrants (mostly retirees) to the village to appreciate the forest's beauty and associated recreational opportunities. Although many would consider the shift to be one from direct dependence to a secondary kind of dependence, others argue that a conservation ethic, now so obvious in this community, can involve "mind and body, reason and passion, intellect and feeling . . . all employed together" (Singh 2013, p. 1). Such emotions might be considered as 'direct' as livelihood dependence.

Those Local men who remain - many have died or moved away-have varying adaptations to the different harp from which they now fashion their songs of identity. Some have grown into bitter, broken men facing despair; others have accepted the change, while mourning their cultural and livelihood losses; a few have been able to adapt, fashioning new songs with the familiar strings of the outdoors, physical strength, dominance and courage.

Whereas previously the forest represented a more substantial source of food, firewood and income, it now largely supplies recreation with a few supplemental goods. It also however still performs a subsistence 'safety net' for those in dire need-of which there are probably more now than in the past when milder poverty, with routine supplementary forest subsistence, was the norm.

The significance of the USFS in the community has also dwindled. There are far fewer employees, many of whom are now women, including the head of the Ranger District (removing some of the assumed inherent masculinity of forest management). Those who remain appear to be remarkably separate from the community. ${ }^{2}$ None live in the community and several expressed their desire to remain separate. ${ }^{3}$ The logging that does take place on federal lands is on the western side of the Olympic Peninsula, far from Bushler Bay. The Olympic National Park is adjacent to the community and used by inhabitants as well. There is broad acceptance that these two institutions should manage the forests (despite complaints about such management). There are still few ways that local people can influence policies there. The conflict that continues to beset the community is now seen as between old-timers and newcomers, one-time loggers and environmentalists, with the latter 'winning'.

There has been a clear diminution of gender differentiation, with an emphasis on men and women or families spending time together in the forest. The repertoire of recognized, forest-based activities is more diverse now, across a broader spectrum of recreational and aesthetic uses and delights, with less significance for masculinities. Men's and women's involvement in these activities is seen as roughly evenly divided, except for logging and hunting, neither of which is particularly dominant vis-à-vis the other activities and both of which remain somewhat more men's activities than women's (see Colfer, Cerveny, and Hummel 2019). 
USFS activities, insofar as I was able to ascertain them, still appear to focus on the forest as a source of timber, with little attention to other uses. USFS funding has diminished consistent with the loss of timber-related income as the forests were closed to logging, and locals complain about lack of USFS or US Park Service attention to roads that would allow recreational access to valued places. Nor are national problems with forest fires elsewhere irrelevant to these reductions in local funding, suggesting worsening future problems based on climate change.

There remain a few men who cling to the forest-related ideals of masculinity described for loggers in Chapter 3 or by Brandth and Haugen (2000) for Norway previously. The retired men, most from urban areas (the amenity migrants), bear some resemblance to the 'organization man' Brandth and Haugen describe. Organization men's ideas about masculinity are closer to those of the Public Employees described in Chapter 3. But most appear to recognize and value more gender equity, less masculine dominance, wider spectra of acceptable sexuality and legitimate forest use, and many express their love of the forest more freely and more emotionally than did earlier inhabitants. This love of the forest (typically shared by Locals as well) represents a potential entrée for forest managers, a resource on which they could draw if they chose to gain fuller understanding and more meaningful links with local communities. The present-day USFS policy that requires employees to shift from place to place every couple of years as they progress professionally is counter-productive and currently makes access to and use of local knowledge more difficult.

Attention to local gender realities would require more two-way communication channels: USFS and US Park Service employees could learn about local, forest-related knowledge, goals and problems; more feedback channels 'up' the bureaucratic ladders could allow stronger local voices in policy and local decision-making. The USFS is already linking with larger, urban-based nongovernmental organizations (NGOs) to make use of volunteers (some residing locally) who help to maintain trails into the Olympic Mountains and other remote areas. There is scope for expansion of this kind of collaboration, but it would require changes in the attitudes of forest managers, and in the institutional context, which currently has little flexibility for bottom up involvement. ${ }^{4}$

The USFS itself has a more ecological approach now than it did in the 1970s, and that could also provide a closer link with the conservation and recreational interests of the current inhabitants.

\section{Forest relevance of Long Segar masculinities}

\section{Long Segar: swiddeners in humid tropical rainforest}

Long Segar 40 years ago represents a stark contrast to Bushler Bay in many ways:

- Dense humid tropical rainforest in Long Segar contrasted with Bushler Bay's temperate rainforest 
- Long Segar's muted gender differentiation vs. the polarized gender of Bushler Bay

- Kenyah traditions emphasizing headhunting, swidden agriculture and routine dependence on a vast repertoire of forest products (see Colfer 2008) vis-à-vis Bushler Bay's American frontier orientation and dependence most fundamentally on logging and efficient tree production and harvest (Colfer and Colfer 1978; Colfer 2018)

Given the very mild gender differentiation, there was little felt need among Kenyah men to focus much attention on demonstrating their masculinity. Thus, changes to their forest-dependence were not as much of a direct attack on their manhood as in Bushler Bay. These changes did however represent an attack on their ethnic identities, which were firmly based in the practice of swidden agriculture. Swidden, in turn, was closely linked to women's gender identities (also less key to women's sense of self than among Bushler Bay's men and, to a lesser extent, women).

The forested environment-a mosaic of primary and secondary forest, new and older swiddens, as well as the village itself - provided men the opportunity to gain and demonstrate forest-related skills, like hunting, fishing, gathering forest products and finding their way through dense forest. Demonstration of such skills represented one path for men to persuade desirable and hardworking women to marry them, gain and maintain the respect of their families and potentially become a village leader in time.

The community was strongly and directly dependent on the forest mosaic as a source of many products, which men (and women) obtained for daily life (timber, firewood, poles, NTFPs, medicinal plants, fibres and almost all food). Even the rice produced in swiddens was dependent on the forest; the soils were poor and required the cycle of cutting, agricultural use and fallow periods of forest regrowth to maintain fertility, a form of 'restoration' not usually recognized. The dangers in the forest - wild animals, accidents, losing one's way, even antagonistic people-served as context for demonstrating courage, strength and knowledge acquisition. These harp strings were also available to and admired for those (fewer) women who plucked such strings (e.g., Box 7.5).

Formal forest managers, the most evident being Americans working at the Georgia Pacific Timber concession, saw local people as potential problems, related to land tenure, labour and potential conflict. Their focus, as in Bushler Bay, was on production, 'getting the logs out'. Like the USFS in Bushler Bay, they had little interest in the community beyond preventing problems and their escalation.

However, there were ways in which closer links between the communities and the companies or the Indonesian Forest Service could have been of mutual benefit. Local people had deep understanding of local forests. Their knowledge would have been more compatible with a style of management now more in vogue, one that recognized the multiple values extant in a forest, beyond just commercially valuable trees. 
An attitude of mutual respect and openness to the potential for valuable inputs from these Kenyah men (and women) would have helped logging companies and government managers manage the forest in ways that were more commercially, ecologically and socially sustainable. A greater variety of commercially valuable products could have been identified with local help, and together mechanisms for managing them sustainably could have been developed.

- Local knowledge of wildlife patterns of behaviour and reproduction could have led to management of wildlife for continued use and contribution to local diets while protecting those as needed (e.g., orangutans and other endangered species).

- Non-timber forest products, like rattan, bamboo, sang (Licuala spp.) and a huge variety of fibres and edible plants, which had subsistence and potential commercial value, could have been studied. Management plans could have been developed collaboratively such that local people and/or companies could harvest them sustainably.

- Medicinal plants were recognized by the Kenyah (Leaman 1996), some of which could well have been commercially valuable-building on local knowledge, as pharmaceutical companies have done elsewhere.

These kinds of interactions between forestry professionals, whether governmental or in private industry, could have prevented the sad situation we now face: The forest is gone, basically. This amazing forest, of value to all of humanity, has now been replaced by a 'forest' of oil palm, with only scrubby remnants of the original forest along the river banks, still used for swiddens, but with unsustainably reduced fallow periods due to lack of access to land (now in the hands of oil palm companies). This change is due far more to government and industry action than to the swiddeners so often blamed (and who co-existed with the forest for centuries).

But there is room for optimism if formal forest managers could be persuaded to work collaboratively with those who remain in the dwindling forested areas. Much of the people's ecological knowledge remains, for the moment, and saving forest-based cultures should be as much of a priority as saving biodiversity.

\section{Kenyah swiddeners in fields of oil palm}

My own sorrows at the loss of the Long Segar forest are clear, and to some extent shared by the Kenyah. However, their perspectives are more optimistic than mine. They are a remarkably adaptable people.

Amazingly, gender differentiation remains muted, despite increasing pressure to conform to longstanding global narratives of masculine superiority. As 'modernity' has made its way into Long Segar, ${ }^{5}$ the churches, mosques, government and to a lesser degree, industry, all sing the song of men's superiority over women.

The Kenyah's near-total dependence on the forest has disappeared with the forest itself. Unlike previously, many foods are bought now. Most forest products 
are no longer available in amongst the oil palms. Kenyah men can no longer demonstrate their strength, fortitude and courage by manoeuvring through the nearby forest, thus obliterating previously important masculine harp strings, avenues to masculine identity. ${ }^{6}$ Trade goods, the most obvious motivation for men to make the expeditions traditionally associated with manhood, are now available locally, removing or at least altering the expedition-making harp string previously so valued.

Denied their role during recent decades as independent or contract loggers by the absence of forests others wanted cleared, Kenyah men are taking up smallscale, local plantation development in concert with the powerful industry actors nearby — strongly preferring independent or semi-independent agroforestry production to wage labour. Where women have taken part-time jobs with the oil palm companies, fewer men have been so inclined.

With only small areas of forest remaining along the river's edge, men's links to forests are disappearing in a process over which they have little control. Yet their sense of adventure and curiosity (and perhaps the flexibility of their own ideas about masculinity) appear to grant them an equanimity in the face of drastic social, cultural and environmental change that was less evident in the Bushler Bay example.

The oil palm industry has shown a willingness to work with communities, though often in a manipulative manner-building on existing intra-community antipathies and exacerbating distrust and factionalism in their attempts to obtain additional land for their plantations. Their presence, much closer geographically to the community than the timber company offices had been, provides examples, knowledge of oil palm cultivation, that local people can follow, and the companies provide infrastructural improvements sometimes (e.g., paving village roads).

I saw no evidence in 2019 of formal Indonesian forestry involvement. But there would be opportunities to work collaboratively to improve the management of the strips along the riverside, perhaps restoring elements of the original forests. Forestry professionals could work with the Kenyah to resuscitate some of the forest products used previously for sale, for subsistence and/or for artistic expression and even for ecological purposes. See e.g., Gibson and Warren (in press), on the efforts of individual men in Australia, Hawaii and the Pacific Northwest of the US, trying to establish the trees that can in the distant future provide the raw materials, now rare, to make fine guitars. Forestry professionals could help link people with, or develop, trade networks ${ }^{7}$ to reinforce such plantings and encourage wildlings, including tree species like ironwood (Eusideroxylon zwageri) or 'honey trees' (Koompassia excelsa) - though Indonesian laws granting rights to all wild trees to the Indonesian government would have to change. ${ }^{8}$ The people and the forestry professionals could together figure out agroforestry strategies that would benefit both the forest and the people, including strip plantings, species needing shade, modernized agroforestry and other well-known techniques.

These actions would not replace the forest or its functions either ecologically or socially, including in terms of masculinities. But they could contribute to 
biodiversity conservation and improve local people's livelihoods and important aspects of their forest-based cultures. Such interaction could strengthen beneficial adaptation of externally planned and implemented policies with profound implications for people's lives and local contexts. The simple act of respecting the knowledge of rural men (and women) would also go far in making Indonesian forest (and other kinds of) management more coherent.

\section{Forest relevance of Sitiung masculinities}

Sadly, I have not been able to return to Sitiung since 2008, to see how masculinities may have changed. However, my last brief visit revealed a landscape covered primarily in oil palm rather than forest. Google Earth shows that the process of conversion has continued apace, as have a series of interviews conducted by Ardi et al. (2020).

Gender differentiation among the three ethnic groups in Sitiung-Minang, Javanese and Sundanese - took intermediate positions between the two extremes of Bushler Bay and Long Segar. The histories of all three resident ethnic groups included dynasties, sultanates or kingdoms ('Great Traditions', à la Redfield 1960) and all three adhered, to varying degrees, to Islamic narratives of masculine superiority. ${ }^{9}$ All of these communities resided in forested areas in the 1980 s, but none would have been considered truly 'forest-based cultures', though all made use of nearby forests.

Masculinities for the Minang focused on cleverness, articulateness, religiosity and making money. Their moneymaking was as likely to involve forest use (often clearing for rice and then rubber or other tree crops) as any other profitable activity. But their masculinities were far less dependent on the forest than those of the Kenyah or Bushler Bay's loggers.

Javanese men (and women) have tended to fear the forest, thus reducing further any links between masculinities and forests. Instead, men's focus tended to be on agriculture and fulfilling the expectations of their place in society (which they as farmers generally perceived to be quite low). In Sitiung 5 , men logged, because it was necessary to clear their fields and because they needed money to survive, but it was not their choice; it was comparatively minimally related to demonstration of their masculinity (only as evidence of hard work and an under-valued version of breadwinning). In the longer established Sitiung 1, men had even fewer links with the forest. Indeed, each family was supposed to have a second hectare designated for rice, but families were reluctant to go out into the forest, figure out which land belonged to them and clear it, satisfied instead to focus on their bulldozed and infertile land nearer the community (labour constraints were also a prime factor).

Many Sundanese shared with the Minang concern with religiosity and making money and with the Javanese, a concern with agricultural production. Many, recognizing the minimal opportunities in Sitiung 5 to make money or to succeed at fishponds, rice or vegetable production, returned to West Java. Rice they deemed more central to their well-being than did the Javanese, who were willing to eat corn when rice crops failed. 
The implications of these views of masculinity reduce the options for formal forest managers' involvement with the communities. The amount of available, traditional knowledge of the forest is less than in Long Segar or Bushler Bay, where forests form important parts of people's identities.

The Indonesian Forest Service's interests (long dominated by the Javanese) have tended to focus on replanting/regreening, which could be emphasized among the Javanese and Sundanese, as there would be little need for these farmers to spend time in the (now nearly non-existent) forest per se. The willingness of the Javanese to comply with bureaucratic dictates also opens doors for topdown planning that is less likely to succeed for the culturally more independent Minang, for instance. Minang interests in trees have been in those with commercial value, so that interest could also be built upon, including forest trees, as the Minang showed little fear of the forest per se (excepting tigers, still a danger in the 1980s). Again, as noted for Long Segar, the legal ownership of wild trees by the government would have to shift to grant community members rights to own such trees. These ethnic groups were more admired within Indonesia and would therefore encounter fewer prejudices and fears from forestry officials, compared to the Kenyah or other Dayaks. This in turn would make collaboration easier. The fact that Ardi and associates (2020) found Sitiung's people to have certificates of ownership of their land (a big change from the past) suggests this may be correct.

The implications of forest loss are also less extreme for these ethnic groups, as their cultural systems can function adequately and adapt with or without forests.

\section{Forest relevance of forestry scientists' masculinities}

There is a range among forestry scientists in the strength of their gender differentiation, influenced by their native cultures as well as that of their work setting. International work settings are likely to include at least lip service and sometimes genuine commitment to global efforts to enhance gender equity. Gender equity does not theoretically require either muted or strong differentiation between men and women; both can probably be equitable.

Although scientists typically recognize and value the masculinities described for a place like Bushler Bay (e.g., physical strength, ability to endure harsh conditions), these are less likely to be the masculinities to which they themselves aspire. Scientists (men) are more likely to pluck the harp strings of adventure and articulateness in speech (as do the Kenyah men of Long Segar), logic in thought (like Minang men) and quantification in analysis (like Americans; what Clarke and Hamilton 2013 call the 'magic counting dragon'). ${ }^{10}$

The global narrative of forests as masculine places provides a convenient rationale for these scientists' traditional focus on timber, the product virtually universally associated with men. However, global efforts both to recognize the forest as a complex biome with values beyond timber and to improve gender equity have strengthened these men's attention to forest values other than timber. These in 
turn have reinforced research on the norms, roles, activities and goals of women as well as men-sometimes leading to a muting of gender differentiation and a broader understanding of forest uses.

The dominance (both numerically and substantively) of men in formal forestry has more commonly resulted in standardized policies designed and implemented with their own interests, concerns and knowledge in mind. They often have access to little understanding of rural forest masculinities or their variability, which has interfered with their ability to tailor their advice, research and planning to rural realities. The variations in rural masculinities have suffered a similar 'invisibility' to that of women in forests (e.g., Arora-Jonsson, González-Hidalgo, and Colfer 2019; Paulson 2017).

Some of the harp strings these scientists pluck for themselves can function to marginalize others. The emphasis of some on control suggests an unwillingness to accept control that local people might legitimately wish to exercise; the interest in demonstrating articulateness can mean a lack of willingness to listen, as is necessary if we want to understand local perspectives.

Making the links called for here will require the involvement of such scientists, researchers and professional foresters. They will benefit from

- Examining and recognizing their own assumptions and being open to seeing alternative masculinities

- Willingness to consider qualitative understandings as legitimate complements to the more familiar quantitative approaches

- Bringing pressure to bear on forest institutions like the US Forest Service or Indonesia's forest bureaucracy to increase their flexibility and their responsiveness to local variation

- Developing and expressing respect for and openness to knowledge that local people have about forests, combined with a willingness to share their own knowledge and approaches in two-way communication

- Monitoring these efforts and adapting those that fail with perseverance

\section{Last words}

I hope that I have succeeded in demonstrating in this book, via this shared journey, some of the variations that characterize masculinities and their differing links with forests in different places and at different times. Such links can range from full and thriving to absent, and many levels of involvement between those two extremes.

The implications of such variation for forest management are significant. We are concerned to enhance the viability of forest management for the forests themselves (and the broader environment) and also for the well-being of the human populations who reside in and near those forests. Forests have been widely defined as masculine settings, based largely on the hegemony of the definitions and narratives coming from the global North, many of which differ 
markedly from those of forest peoples. This needs to change if we have any hope to keep the world's forests for coming generations.

\section{Notes}

1 One can easily see the parallels with communities in the global South.

2 In my 2017 re-visit, for instance, I contacted the director ahead of time about the planned research on gender, community and forests, worked closely with USFS research personnel in their area (Portland, OR and Seattle, WA), and had the prestige of Cornell University and the Center for International Forestry Research behind me. Yet to my amazement, no one showed up for the meeting they had scheduled for me. After several attempts, the director agreed reluctantly to spend 10-15 minutes with me, before rushing off to take care of her home repairs. I was able to talk with a couple of employees informally, but one called afterwards to make doubly certain the opinions expressed would remain confidential, fearing adverse responses from supervisors. These are not the actions of an institution interested in local communities or gender. A certain paranoia is likely based on the longstanding conflict.

3 I heard statements like, "I don't mix with the community", from several newcomers and longer-resident Public Employees.

4 One encouraging possibility exists in the USDA's Collaborative Forest Landscape Restoration Program; see e.g. Butler and Schultz 2019; Walpole et al. 2017; Wagner and Fernandez-Gimenez 2008.

5 Even some of the oldest people have and use cell phones, as they sit in traditional fashion on their front porches, watching the world go by. Young people use Facebook regularly, keeping in touch with their relatives all over East Kalimantan (a few in Jakarta and at least one anthropologist in the US). There are computers, flash drives and Wi-Fi available in the village office, and there's now a small library.

6 Several Kenyah men and I got lost in the exactly replicated matrix formed by the local oil palm plantations in March 2019. They were as clueless as I about how to find our way out.

7 Such collaboration was successfully undertaken in a number of countries within the Adaptive Collaborative Management Program at CIFOR (see www.cifor.org/acm/).

8 See https://forestlegality.org/risk-tool/country/indonesia (accessed 16 August 2019), for a sense of the complexity of Indonesian forest management laws and regulations. Larson et al. (2019) document the reform efforts (and level of success) focused on community use of forests.

9 Remembering of course that Indonesian societies are nowhere near the extreme gender differentiation of Middle Eastern versions of Islam or masculinities.

10 “'The 'MCD' [magic counting dragon] is a symbol representing the cultural forces that confer a kind of security and legitimacy in human activity. In an era of scientific inquiry marked by what has been called 'the statistical style' . . numbers are a central feature of our magic system ...." (p. 31).

\section{References}

Ardi, with Zumroatun Nikmah, Nori Helpita, Arjunawati, Siska Purnama Sari, Zulkifli, Alprian Apred S., and Rahmat Hidayat. 2020. Hasil Survei Sitiung 2020. Report Generated for Colfer in Response to Her Questions about Sitiung Currently.

Arora-Jonsson, Seema, Marien González-Hidalgo, and Carol J. Pierce Colfer. 2019. "Towards a Future Forest (and Feminist) Agenda: Acknowledging 'the Invisible' in Forestry Relations." Human Ecology, submitted to.

Brandth, Berit, and Marit S. Haugen. 2000. "From Lumberjack to Business Manager: Masculinity in the Norwegian Forestry Press." Journal of Rural Studies 16:343-355. 
Butler, William H., and Courtney A. Schultz, eds. 2019. A New Era for Collaborative Forest Management: Policy and Practice Insights from the Collaborative Forest Landscape Restoration Program. London: Earthscan/Routledge.

Clarke, Paula K., and W. Ted Hamilton. 2013. "The Value of Anthropology: Noticing and Challenging the Magic Counting Dragon.” Anthropology News:31.

Colfer, Carol J. Pierce. 2008. The Longhouse of the Tarsier: Changing Landscapes, Gender and Well Being in Borneo. Edited by G. N. Appell and Vinson H. Sutlive. Vol. 10, Borneo Research Council Monograph Series. Phillips, ME: Borneo Research Council, in cooperation with CIFOR and UNESCO.

Colfer, Carol J. Pierce. 2018. "Before and After the 'Timber Wars': Context, Change and Potential Collaboration on the Olympic Peninsula." Humboldt Journal of Social Relations 40:137-162.

Colfer, Carol J. Pierce, Lee Cerveny, and Susan Stevens Hummel. 2019. "Using Rapid Rural Appraisal Tools to Explore Gender and Forests in the Global North." Human Organization 78 (1):12-27.

Colfer, Carol J. Pierce, with A. Michael Colfer. 1978. "Inside Bushler Bay: Lifeways in Counterpoint." Rural Sociology 42 (2):204-220.

Gibson, Chris, and Andrew Warren. in press. "Keeping Time with Trees: Climate Change, Forest Resources, and Experimental Relations with the Future." Geoforum, Vol. 108, January 2020, 325-337. https://doi.org/10.1016/j.geoforum.2019.02.017.

Harding, Sandra. 2004. "A Socially Relevant Philosophy of Science? Resources from Standpoint Theory's Controversiality." Hypatia 19 (1):25-46.

Larson, Anne M., Iliana Monterroso, Nining Liswanti, Tuti Herawati, Abwoli Banana, Pamela Cantuarias, Karin Rivera, and Esther Mwangi. 2019. "Models for Formalizing Customary and Community Forest Lands: The Need to Integrate Livelihoods into Rights and Forest Conservation Goals." CIFOR InfoBrief 253:8. https://doi. org/10.17528/cifor/007273.

Leaman, D. J. 1996. "The Medicinal Ethnobotany of the Kenyah of East Kalimantan (Indonesian Borneo).” Dissertation, University of Ottawa.

Paulson, Susan. 2017. "Changing Masculinities and Femininities in the (Re)Production of Andean Silvopastoral Systems." In The Earthscan Reader on Gender and Forests, edited by Carol J. Pierce Colfer, Marlène Elias, Bimbika Sijapati Basnett, and Susan Stevens Hummel, 163-280. London: Earthscan/Routledge.

Redfield, Robert. 1960. Peasant Society and Culture. Chicago, IL: University of Chicago Press.

Rosendahl, J., M. A. Zanella, S. Rist, and J. Weigelt. 2015. “Scientists' Situated Knowledge: Strong Objectivity in Transdisciplinarity." Futures 65:17-27. http://doi.org/10.1016/j. futures.2014.10.011.

Singh, Neera M. 2013. "The Affective Labor of Growing Forests and the Becoming of Environmental Subjects: Rethinking Environmentality in Odisha, India.” Geoforum 47:189-198.

Wagner, Cheryl L., and Maria E. Fernandez-Gimenez. 2008. "Does Community-Based Collaborative Resource Management Increase Social Capital?” Society and Natural Resources 21:324-344. https://doi.org/10.1080/08941920701864344.

Walpole, Emily H., Eric Toman, Robyn S. Wilson, and Melanie Stidham. 2017. "Shared Visions, Future Challenges: A Case Study of Three Collaborative Forest Landscape Restoration Program Locations.” Ecology and Society 22 (2). https://doi.org/10.5751/ ES-09248-220235. 